\title{
ДИДАКТИЧНА ФУНКЦІЯ ФОРМУВАННЯ АЛГОРИТМІЧНОГО МИСЛЕННЯ
}

\author{
Володимир Сарієнко \\ кандидат педагогічних наук, \\ доцент кафедри природничо-математичних \\ дисциплін та інформатики у початковій освіті, \\ ДВНЗ «Донбаський державний педагогічний університет» \\ м. Слов’янськ, Україна \\ vsar@ukr.net
}

\begin{abstract}
Анотація. У статті зазначено, що алгоритмічне мислення $\epsilon$ продуктом розвитку нових інформаційних технологій. 3'ясовано, що значна частина процесу алгоритмічного мислення припадає на період шкільного навчання. У зв'язку з цим перед освітою постає проблема дидактичного забезпечення розвитку такого мислення. У статті висвітлено зміст алгоритмічного мислення й умови його формування. Визначено структуру логічного апарату та дидактичні засоби озброєння ним школярів у процесі навчання. Розкрито методичні підходи до формування операційних структур мислення. У цьому питанні зазначено, як один 3 ключових моментів функціонування алгоритмів, факт, що алгоритм є одним із видів загальних методів діяльності взагалі, а не лише діяльності розумової. Розкрито структуру алгоритмічного процесу та зміст його етапів, що становить основу керування процесом формування алгоритмічного мислення в школярів.
\end{abstract}

Ключові слова: алгоритм; алгоритмічне мислення; логіка пізнавального процесу; логічний апарат; навчальний процес; інформаційні технології; розумові операції.

Постановка проблеми в загальному вигляді. Розвиток і впровадження нових інформаційних технологій активно впливає на темпи розвитку суспільноекономічних відносин, виникають нові форми інформаційних зв'язків, формується суспільство з гнучким динамічним мисленням, здатне до конструктивної самооцінки та вибору цілей і шляхів розвитку, швидкої й адекватної реакції на зміни зовнішнього та внутрішнього середовища. Тому сьогодення дає освітянам важливе соціальне замовлення - готувати майбутнє покоління до самостійного, творчого пізнання навколишнього світу, навчити його користуватися обчислювальною технікою, познайомити зі способами організації та обробки інформації, виробити в учнів особливий стиль мислення, що відповідає нагальним задачам: алгоритмічне мислення.

Нині алгоритмічне мислення тісно пов'язують із комп'ютерною грамотністю. Дійсно, здатність розробляти й використовувати алгоритми основний елемент комп'ютерної грамотності. Але алгоритмічне мислення - це значно ширше поняття. Воно стосується повсякденної нашої діяльності як на практиці, так і в навчанні. Адже ми щоденно складаємо алгоритми різних дій.

Користування алгоритмічними прийомами мислення в будь-якій ділянці практичної діяльності стає вимогою часу, повз якої школа пройти не може. 
Національна доктрина розвитку освіти України у XXI столітті висуває одним із завдань, які стоять перед сучасною освітою, підготовку людей високої освіченості й культури, кваліфікованих спеціалістів, здатних до творчої праці, професійного розвитку, мобільності в освоєнні та впровадженні новітніх наукомістких й інформаційних технологій. Навчання найпростішим алгоритмам і використання їх у шкільній практиці дисциплінує школяра, привчає його до порядку й організованості мислення. Отже, виходячи із зазначених вимог, завдання, організація розвитку алгоритмічного мислення школярів висуває перед наукою низку дидактичних задач, серед яких розкриття змісту дидактичної функції формування алгоритмічного мислення посідає чинне місце і 3 цих позицій є актуальним.

Аналіз основних досліджень i публікацій. Питанню розвитку алгоритмічного мислення школярів у процесі навчання присвячено велику кількість досліджень. Фундаментальною основою досліджень зазначеного питання $\epsilon$ роботи психологів П. Гальперіна, В. Давидова, Л. Ланди, І. Тализіної та ін. Зокрема, у розробленій теорії поетапного формування розумових дій П. Гальперін виділяє 5 послідовних етапів формування розумових дій під час навчання, які створюють основу алгоритмічного мислення. Н. Тализіною розроблені методи моделювання різних видів пізнавальної діяльності та принципи управління процесом їхнього формування; сформульована діяльнісна концепція програмованого навчання. Л. Ландою конкретно розроблялися питання алгоритмізації та теорії й методики програмування. В. Давидов досліджував психологічні закономірності побудови розумових дій у процесі навчання.

О. Воробей, О. Пасічник, О. Рибалко присвятили свої дослідження дидактичним питанням викладання алгоритмізації в школі. Зокрема, О. Рибалко розглядав ці питання в системі початкової освіти. М. Махмутов розглядав упорядковану систему пізнавальних дій як основу проблемного навчання. Питанням формування комп'ютерної грамотності присвятив свої дослідження I. Тесленко. Значну базу досліджень зазначеного питання склали дослідження й інших дослідників.

Формулювання цілей статті. Метою статті $\epsilon$ висвітлення впливу застосування алгоритмічних дій на оволодіння школярами алгоритмічними прийомами мислення як фактором активізації навчально-пізнавального процесу.

Результати дослідження. Невичерпні можливості сучасних інформаційних технологій часто залишаються невикористаними через неготовність нашого мислення до засвоєння та активного використання законів i логіки світу комп'ютерів. Тому формування алгоритмічної грамотності повинно здійснюватися на основі формування основних логічних структур мислення, яке, за твердженням психологів, найбільш сприятливе в молодшому шкільному віці.

Останнім часом у зв'язку з розвитком ЕОМ з'явився новий термін «інформаційна грамотність». У це поняття входить насамперед розуміння 
поняття інформації й уміння ії виражати, організовувати й планувати свої дії у взаємозв'язку з навколишнім. 3 такого погляду, інформатика - це наука, яка досліджує структуру та загальні властивості інформації, а також закони і методи нагромадження, збереження, переробки, пошуку та використання інформації в різноманітних областях людської діяльності.

Під інформацією розуміють будь-яку сукупність сигналів, впливів, відомостей, які та чи інша система сприймає від навколишнього середовища (вхідна інформація), зберігає в собі (внутрішня інформація) або видає в навколишнє середовище (вихідна інформація).

Початкові фундаментальні знання інформаційної грамотності групуються навколо поняття «алгоритм». Спочатку термін «алгоритм» уживався для позначення десяткової позиційної арифметики та алгоритмів цифрових обчислень, а потім - для позначення будь-яких алгоритмів [6].

Тривалий час цим терміном користувалися лише математики, розуміючи під ним правила розв'язання задач. Тепер алгоритм розглядається як зрозуміла й точна вказівка виконавцю здійснити послідовність дій, спрямованих на досягнення зазначеної мети чи на розв'язання поставленої задачі. Поняттям алгоритму широко користуються в найрізноманітніших галузях науки, техніки, виробництва. У багатьох випадках результат діяльності людини безпосередньо залежить від того, наскільки чітко відчуває вона алгоритмічну суть своїх дій: що робить у певний момент, у якій послідовності, який передбачує результат тощо. Усе це визначає особливий стиль культури мислення й поведінки людини. Тому формування алгоритмічного мислення учнів - важливе й актуальне завдання школи на сучасному етапі.

Проблема навчання учнів загальним методам мислення - не лише методична, але й важлива загальнодидактична та психологічна проблема, бо з іiі розв'язанням пов'язано формування тих загальних якостей розуму, які мають значення для засвоєння будь-якого предмета й підготовки до будь-якого виду діяльності.

Формування операційних структур мислення являє собою закріплення правил розв'язання певних класів задач у самій структурі розумової діяльності, у системах зв'язків, які визначають ії походження. Шлях тут такий. Спочатку усвідомлюються об'єкт, задача, властивості об'єкта, які визначають принципи розв'язання задачі, самі ці принципи, спосіб розв'язання, який із них випливає. Потім спосіб і принципи розв'язання закріплюються в певних системах стійких мозкових зв'язків. У корі головного мозку ніби створюється готовий, автоматично діючий механізм, який, отримавши відповідні початкові дані й завдання, одразу спрацьовує і здійснює всі необхідні для розв'язання дії над початковими даними, “не замислюючись”, а найчастіше не усвідомлюючи, чому він так робить. Система таких асоціативних механізмів для розв'язання певних класів задач і складає операційну структуру мислення. 
О. Рибалко [7] вважає, що опорою операційного стилю мислення є такі вміння й навички:

- планувати послідовність операцій (кроків), які потрібно виконати, щоб досягти поставленої мети;

- виділяти й описувати властивості будь-якого об'єкта;

- організовувати пошук відомостей (інформації), потрібних для розв'язання того чи того завдання;

- чітко виконувати правила оперування цим об'єктом;

- свідомо використовувати клавіатуру обчислювальних пристроїв.

Підтверджує цю саму думку й О. Воробей [1], додавши вміння алгоритмічно мислити, тобто подавати складні дії у вигляді певної послідовності простіших.

Розумові операції - це засвоєні й автоматизовані способи пізнавальної діяльності. Останнім часом ця концепція отримала своє педагогічне застосування в різних теоріях алгоритмізації навчання ([3], [9] та ін.). Під «алгоритмічним підходом» у психології i педагогіці мають на увазі алгоритмізацію в навчанні, тобто розробку й навчання учнів алгоритмам розв'язання певних предметних задач, а також побудову алгоритмів самого навчання, тобто алгоритмів, котрі використовує викладач у своїй навчальній роботі [9]. Для педагогіки значення алгоритмів полягає в тому, що навчивши учнів деякому алгоритмічному розв'язанню задач, ми даємо йому не лише спосіб керування тими об'єктами, які він буде перетворювати за допомогою цього алгоритму, але й спосіб керування самим собою, своїм мисленням і практичними діями. Алгоритм є одним із видів загальних методів діяльності взагалі, а не лише діяльності розумової.

У методиці недостатньо розроблене питання про те, як формувати поняття, що є основою розпізнавання предметів і розв'язання задач, як далі на основі цих понять будувати найбільш економічні, раціональні, ефективні алгоритми їхнього застосування та як цим алгоритмам навчати. Л. Ланда [3] вважає, що в навчанні учнів алгоритмам і в формуванні в них алгоритмічних процесів можна йти різними шляхами. Один із них - давати учням алгоритм у готовому вигляді, розпочинати з навчання алгоритмічним вказівкам. Такий шлях, однак, часто не $\epsilon$ кращим, хоча в деяких випадках, у певних умовах навчання з метою економії часу учням доцільно давати й готові алгоритмічні вказівки. Але навіть у цих умовах для свідомого засвоєння й використання алгоритмів учні повинні добре орієнтуватися в змісті того матеріалу, із яким необхідно за допомогою алгоритму оперувати, знати відповідні закономірності явищ, їхні істотні ознаки. У загальному ж випадку 3 педагогічного погляду значно краще, коли учень відкриває відповідні алгоритми сам (якщо, звичайно, ця задача для нього посильна) чи за допомогою вчителя, а не одержує їх у готовому вигляді. Таким шляхом доцільно йти не лише при навчанні математиці, але і при навчанні іншим предметам. Вивчення явищ слід розпочинати не 3 того, що давати учням алгоритм розпізнавання цього явища й оперування ним, а 3 ознайомлення зі 
змістовною стороною цього явища, із його особливостями, із його відношеннями 3 іншими явищами, тобто з формування поняття про нього.

У методиці виникає ще одне питання: чи не приведе навчання алгоритмам до «шаблонізації» мислення учнів, чи не виникне при цьому небезпека стримування їхніх творчих сил?

Л. Ланда [4] вважає, що навчання алгоритмам ні в якій мірі не зводиться до оволодіння готовими алгоритмами, до заучування їх. Правильно побудоване навчання алгоритмам неодмінно передбачає навчання самостійному відкриттю, побудові, формуванню алгоритмів, а це, як правило, уже процеси творчого характеру. 3 одного боку, алгоритм - це схема, а з іншого - крок до творчості. Навчання алгоритмам необхідне й тому, що якщо для розв'язання деякої задачі необхідно зробити якусь кількість послідовних кроків, то незнання, невиконання або неправильне виконання будь-якої з цих операцій веде до помилки. Якщо учня цим операціям, сформульованим у вигляді алгоритмів, навчити, то він досить швидко й легко оволодіє правильним методом рішення, правильним способом міркувань і дій. Якщо ж цим операціям не навчати, то він буде змушений відкривати їх сам, вступаючи на шлях «спроб та помилок».

На це ж питання дає відповідь і найбільш розроблена в літературі психологічна теорія інтелектуального розвитку: теорія поетапного формування розумових дій, яка базується на працях П. Гальперіна [2] та Н. Тализіної [8].

Як показав П. Гальперін, розвиток у дітей способів розв'язання задач починається з практичного засвоєння дитиною певних означень речей та явищ. Він досягається тим, що виділені в означеннях властивості та відношення використовуються для розв'язання певних завдань, тобто стають потрібними як орієнтири доцільної дії. Він виділяє 5 етапів формування розумових дій під час навчання:

1. Складання схеми орієнтовної основи дії.

2. Формування iіi в матеріалізованому вигляді.

3. Формування дії як зовнішньо-мовленнєвої.

4. Формування дії в зовнішньому мовленні (про себе).

5. Формування дії у внутрішньому мовленні.

3 погляду кібернетики, Л. Ланда вважає можливим розглядати навчання як керування, у певному розумінні, формуванням і розвитком психічних процесів і якостей особистості. Виявляється, що багато процесів, які вважалися творчими, мають алгоритмічну природу. Автор виділяє в мисленні елементарні розумові акти (операції) й умови, у відповідь на які ці операції виконуються. Послідовна перевірка умов і виконання дій утворюють схему, формалізацією якої може бути вираз із операторів, логічних умов та нумерованих стрілок. Це відома формула Ляпунова-Шестопал, яка виявляється придатною для опису алгоритмів у навчанні. Однак із вихідним поняттям «операція» у навчанні виникають труднощі. Наприклад, часто деякі операції неможливо виконати: «Викликати інтерес», «Викликати увагу» тощо. Окрім того, операції, що є елементарні на 
одному рівні знань чи для одних учнів, не $є$ елементарні в інших умовах, $\mathrm{i}$ питання може бути розв'язане лише за допомогою експерименту.

Говорячи про алгоритми, Л. Ланда бачить мету навчання алгоритмам у «...виділенні ознак, а шлях до неї - у свідомій і активній перевірці їх шляхом дій за розгорненими алгоритмами» [3, с. 262]. 3 експериментальних даних Л. Ланда приходить до таких висновків:

1. Алгоритми навчання дають змогу не лише повідомляти та контролювати знання, але й адаптувати навчання до індивідуальних особливостей учнів.

2. Алгоритми із засобів керування об'єктами поступово перетворюються в засоби керування мисленням.

3. Формування методів мислення - канал, по якому здійснюється виховання розумових здібностей учнів.

4. Розв’язання задач за допомогою алгоритмів - одна з умов розвитку інтуїції.

Оволодіння розумовою діяльністю призводить до того, що перш ніж приступити до загальної діяльності, яка спрямована на досягнення бажаної мети, людина планує дії розумово, оперуючи образами й мовленнєвими символами.

Звідси походить концепція навчання як керування розумовою діяльністю школяра. В iï основі лежить навчання розумовим операціям і діям шляхом організації відповідних предметних (наочних) і мовленнєвих дій учнів.

Згідно з теорією М. Махмутова [5], який розглядав взаємозв'язок методів і прийомів наукового дослідження з методами, які застосовуються в навчанні, пізнавальний процес в аспекті його проблемності складається 3 таких етапів:

- виникнення проблемної ситуації;

- аналіз ситуації та постановка проблеми;

- спроба розв’язання проблеми відомим способом;

- пошук нового способу розв’язання шляхом висування пропозицій;

- знаходження нового способу розв'язання шляхом здогадки;

- реалізація знайденого принципу розв’язання шляхом: а) здогадки (інтуїції); б) обгрунтування гіпотези та їі доведення.

Залежно від характеру невідомого проблеми можуть бути різних видів: евристична; фіксована; алгоритмічна.

Алгоритмічна проблема - ситуація, у якій можна застосовувати готові, раніше засвоєні алгоритми.

Уміння застосовувати алгоритм до конкретної умови завдання тісно пов'язане з його реалізацією. Таким застосуванням алгоритмів $\epsilon$ алгоритмічний процес. Він складається 3 декількох самостійних етапів, кожен із яких призначений для переведення даних з одного стану в інший.

Повна побудова алгоритмів складається 3 декількох основних етапів:

1. Постановка завдання.

2. Побудова математичної моделі.

3. Розробка алгоритму. 
4. Реалізація алгоритму (складання програми).

5. Аналіз алгоритму і його складності.

6. Відпрацювання і виконання програми.

7. Аналіз і обробка результатів рахування.

8. Документування алгоритмів і програм.

Висновки 3 дослідження і перспективи подальших розвідок у цьому напрямі. Отже, бачимо, що проблема керування процесами мислення учнів під час навчання завжди була й залишається однією з найважливіших як у педагогіці, так і в психології. Адже для розв'язання задач людині необхідні не лише знання, але й володіння відповідними методами та прийомами мислення, серед яких алгоритмічні прийом посідають одне з провідних місць. Ось чому навчання учнів цим прийомам і методам - одна 3 найважливіших сторін підготовки їх до практичної й теоретичної діяльності.

\section{СПИСОК ВИКОРИСТАНИХ ДЖЕРЕЛ}

1. Воробей, О. О. (2014). Викладання основ алгоритмізації у 5 класі. Комп'ютер у школі та сім'ї, 2, 7-10.

2. Гальперин, П. Я. (1959). Развитие исследований по формированию умственных действий. Москва, Россия: Психология.

3. Ланда, Л. Н. (1966). Алгоритмизачия в обучении. Москва, Россия: Просвещение.

4. Ланда, Л. Н. (1965). Алгоритмы и программное обучение. Некоторые вопросы теории и методики программирования. Москва, Россия.

5. Махмутов, М. И. (1975). Проблемное обучение. Москва, Россия: Педагогика.

6. Пасічник, О. В. (2014). Розвиток алгоритмічного мислення на уроках інформатики. Комп'ютер у шиколі та сім'ї, 7, 13-18.

7. Рибалко, О.О.(2014). Алгоритми та математика у початковій школі. Комп'ютер у школі та сім'ї, 3, 26-30.

8. Талызина, И. Ф. (1989). Управление процессом усвоения знаний. Москва, Россия: Просвещение.

9. Тесленко, І. Ф. (Ред.). (1987). Формування комп'ютерної грамотності учнів. Київ, Україна: Рад. школа.

\section{ДИДАКТИЧЕСКИЕ ФУНКЦИИ ФОРМИРОВАНИЯ АЛГОРИТМИЧЕСКОГО МЫШЛЕНИЯ}

\section{Владимир Сариенко}

кандидат педагогических наук, доцент кафедры естественно-математических дисциплин и информатики в начальном образовании,

ГВУЗ «Донбасский государственный педагогический университет»

$$
\begin{gathered}
\text { г. Славянск, Украина } \\
\text { vsar@ukr.net }
\end{gathered}
$$

Аннотация. В статье указано, что алгоритмическое мышление является продуктом развития новых информационных технологий. Выяснено, что значительная часть процесса алгоритмического мышления приходится на период школьного обучения. В связи с этим перед образованием встает проблема дидактического обеспечения развития такого мышления. В 
статье освещены содержание алгоритмического мышления и условия его формирования. Определена структура логического аппарата и дидактические средства ознакомления с ним школьников в процессе обучения. Раскрыты методические подходы к формированию операционных структур мышления. В этой связи указан, как один из ключевых моментов функционирования алгоритмов, факт, что алгоритм является одним из видов общих методов деятельности вообще, а не только деятельности умственной. Раскрыта структура алгоритмического процесса и содержание его этапов, что составляет основу управления процессом формирования алгоритмического мышления у школьников.

Ключевые слова: алгоритм; алгоритмическое мышление; логика познавательного процесса; логический аппарат; учебный процесс; информационные технологии; мыслительные операции.

\title{
DIDACTIC FUNCTION OF FORMING ALGORITHMIC THINKING
}

\author{
Volodymyr Sariienko \\ Candidate of Pedagogical Sciences, \\ Associate Professor of the Department of Natural and Mathematic Disciplines and \\ Information Technology in Primary Education \\ SHEE "Donbas State Pedagogical University" \\ Sloviansk, Ukraine \\ vsar@ukr.net
}

\begin{abstract}
The article notes that algorithmic thinking is a product of the development of new
\end{abstract} information technologies. The relevance of the article is determined by the need for an adequate display of modern social and scientific and technical processes in human mental activity. The radical changes brought about by the demands of the information society caused the need for developing a new style of thinking - algorithmic thinking. Its essence lies in the operational mode of thinking, in which a ready, automatically acting mechanism is created in the cerebral cortex, which, having received some initial data and tasks, automatically works and carries out all the necessary data for solving the initial data.

The article reveals a close connection between algorithmic thinking and information literacy - the fundamental knowledge of information literacy is grouped around the concept of an algorithm, as understood and precisely directed to the performer in performing a sequence of actions aimed at achieving a specific goal or solving a problem.

The article considers the development of algorithmic thinking both as a methodical problem and as a general educational and psychological problem, since its solution is related to the formation of those common properties of thinking that are important for mastering any subject and preparing for any type of activity. The article reveals the content and methodology of the formation of operational structures of thinking. The initial position is the essence of mental operations as learned and automated methods of cognitive action. The methodical message in the article is based on the didactic position in the meaning of algorithms, which is that, having taught students algorithmic problem solving, the student gets not only a way to control the objects that he will convert using this algorithm, but also a way to control his thinking and practical actions.

The author emphasizes on that the methodology does not sufficiently elaborate the issue of teaching schoolchildren the structure of formation and the rules for formulating concepts, how to recognize objects, what signs underlie the description of concepts, what is the composition of the logical means that underlie the description of concepts. The situation is analogous to the logic and algorithms of the explanation and prescription procedures. It is noted that the solution of these didactic tasks opens the way to independent cognitive activity, creative search. It is noted that the 
effectiveness of the cognitive process will be significantly higher if the student discovers the corresponding algorithms him/herself or with some help from the teacher, and does not receive them in finished form.

The article reveals the structure of the algorithmic process, its content and conditions, which forms the basis for managing the process of the formation of algorithmic thinking among schoolchildren.

Key words: algorithm; algorithmic thinking; logic of the cognitive process; logical apparatus; educational process; information technologies; mental operations.

\section{REFERENCES (TRANSLATED AND TRANSLITERATED):}

1. Vorobey, O. O. (2014). Teaching Fundamentals of Algorithmization in Grade 5. Komputer v shkoli ta simi, 2, 7-10.

2. Galperin, P. Ya. (1959). Development of research on the formation of mental actions. Moscow, Russia: Psikhologiya.

3. Landa, L. N. (1966). Algorithmization in Education. Moscow, Russia: Prosveshchenie.

4. Landa, L. N. (1965). Algorithms and software training. Some questions of the theory and methodology of programming. Moscow, Russia: Prosveshchenie.

5. Makhmutov, M. I. (1975). Problem learning. Moscow, Russia: Pedagogika.

6. Pasichnyk, O. V. (2014). Development of algorithmic thinking in computer science classes. Komputer v shkoli ta simi, 7, 13-18.

7. Rybalko, O. O. (2014). Algorithms and mathematics at elementary school. Komputer $v$ shkoli ta simi, 3, 26-30.

8. Talyzina, I. F. (1989). Managing the process of learning. Moscow, Russia: Prosveshchenie.

9. Teslenko, I. F. (Ed.). (1987). Formation of computer literacy of students. Kyiv, Ukraine: Radianska shkola.

Матеріали надійшли до редакції 22.11.2018 р. 